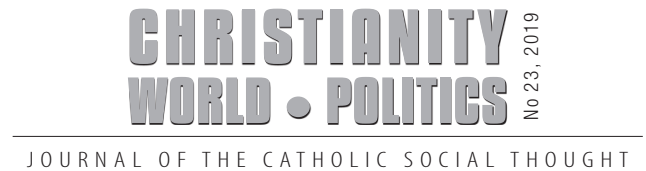

Fred Lazin

Ben Gurion University, Israel

\title{
The changing context of Jews in American Politics - 1930s to the Trump Era
}

\begin{abstract}
Abstrakt: Celem artykułu jest pokazanie, w jaki sposób zmieniał się status Żydów w Ameryce od lat trzydziestych ubiegłego wieku do czasów obecnych. Zaprezentowane analizy skupiają się na amerykańskiej polityce wobec imigracji Żydów do USA, stosunku amerykańskiego społeczeństwa i władz politycznych do Żydów oraz wpływie żydowskich organizacji na politykę amerykańską. Autor wyodrębnia trzy okresy charakteryzujące się różnym statusem Żydów w USA. Wnioskiem płynącym z przeprowadzonych analiz jest teza, iż Żydzi w USA przeszli drogę od etnicznej i religijnej mniejszości, która znajdowała się na marginesie społeczeństwa i polityki do bycia wpływowym i zaliczanym do głównego nurtu aktorem w amerykańskiej polityce.
\end{abstract}

Słowa kluczowe: Żydzi, USA, Trump, aktorzy polityczni

\begin{abstract}
The aim of the article is to show how the status of Jews in America changed from the 1930s to the present. The presented analyses focus on American politics regarding Jewish immigration to the USA, the attitude of American society and political authorities towards Jews, and the influence of Jewish organizations on American politics. The author distinguishes three periods characterized by different status of the Jews in the USA. The conclusion from the conducted analyses is the thesis that Jews in the USA went from an ethnic and religious minority, who was on the margins of society and politics to being an influential and mainstream actor in American politics.
\end{abstract}

Keywords: Jews, USA, Trump, political actors

\section{Introduction}

This article addresses the changing status of Jews in American politics from the 1930's to the present. During this time their status evolved from being outsiders to mainstream actors. The analysis focuses on three periods. The first, the nineteen-thirties, deals with the response of American Jews to Hitler's anti-Jewish 
policies. American Jewish defense organizations urged President Roosevelt to protest against these policies. They also favored the admission of German Jews under the immigration quotas. The second, the nineteen=-seventies and -eighties, covers the American Jewish advocacy movement for Soviet Jewry which began in the late nineteen-sixties and culminated in 1988-1989 when the Soviet Union allowed free emigration for Jews and granted religious and cultural rights to those that remained. The final section discusses the 2016 Presidential campaign which resulted in the victory of the Republican candidate Donald J. Trump over his Democratic rival Hillary Rodham Clinton. The campaign marked a possible change in the socio-political environment in the United States which threatened the status and sense of security among American Jews.

\section{The 1930s; The American Jewish response to Hitler's anti-Jewish policies} Adolph Hitler came to power in March 1933 [Lazin 1979]. Initially, his regime began ousting Jews from Germany's economy, society, and cultural life. ${ }^{1}$ Until the German invasion of the Soviet Union in June 1941, German (and Austrian) Jews could leave Germany.

For most German Jews who wanted to emigrate, however, the major obstacle became finding a country willing to admit them. Much of the world had yet to recover from the economic depression of 1929. Virtually no country wanted to accept refugees, and many had even less desire to welcome Jewish refugees. Following Germany's annexation of Austria in March 1938, President Roosevelt called an international conference in Evian France to deal with the plight of Jewish refugees [Bauer 1974: 231-236]. Participating countries, including the United States, offered few places of refugee for European Jews wanting to flee Hitler's Third Reich.

The promulgation of the Nuremberg Laws in 1935 denied citizenship to German Jews and eliminated and or restricted their employment in many fields. Kristallnacht, the state organized pogrom of November $9^{\text {th }}$ and 10th, 1938, resulted in more than one thousand synagogues and prayer rooms destroyed, seven thousand Jewish shops and businesses vandalized and tens of thousands of Jewish males under arrest [Volker 2016: 670-676].

1 There is no evidence to suggest the existence of a master plan of genocide in the early 1930s [Bauer 1981: 20-21]. By 1945 Hitler's Final Solution had murdered six million European Jews. In his biography of Hitler, Volker argues [2016: 658] “...he never lost sight of his "final goal”- - the eradication of European Jews. In the beginning, however, "eradication" meant displacement and not mass murder." In late 1937 Goebbels noted "Jews must leave Germany and all of Europe." 
The most prominent and influential American Jewish defense organization at the time was the American Jewish Committee (AJC). Established in 1906 in response to pogroms in Russia it consisted mostly of wealthy American Jews of German origin.2 Most of its small membership resided in New York City with some members in other American cities. AJC leaders saw themselves as representing (speaking for) American Jewry. ${ }^{3}$ With few exceptions, they were non-religious Jews. ${ }^{4}$ Two AJC members, Judge Irving Lehman and Mr. Samuel Rosenman served on President Roosevelt's staff.

With each new anti-Jewish policy of the Hitler regime, the AJC asked the State Department and the White House to protest. But, neither spoke out against Hitler or his anti-Jewish policies. The State Department considered these policies to be an internal German matter. ${ }^{5}$ In dealing with the President and the State Department, AJC preferred a quiet, behind the scenes, approach; it opposed active public protests and demonstrations especially by Jews. At one time, AJC urged Protestant ministers to protest State Department policy [Lazin 1979: 291]. President Roosevelt protested Hitler's anti-Jewish policies only after the Kristallnacht Pogrom in November 1938; he recalled his Ambassador from Germany [Lazin 2005: 296]. Throughout the period, the AJC defended both President Roosevelt and the State Department against criticism by other American Jewish individuals and organizations.

AJC also favored entry of German Jews to the United States within the immigration quotas. In 1933, influenced by the depression and high unemployment most Americans and members of Congress supported the quota system which restricted immigration.6 Also, many Americans opposed immigration of Jews. ${ }^{7}$ AJC leaders feared that to suggest an increase beyond the quota limitation of twenty five thousand per year for immigrants born in Germany would likely lead to Congress

2 The overwhelming majority of American Jews at the time had come from Eastern Europe between 1880 and World War I.

3 They can best be described as Shtadlanim, the Yiddish word for self-chosen leaders of the community.

4 Dr. Cyrus Adler, the President during most of the 1930s, was an observant Jew (religious).

5 Initially, Judge Irving Lehman urged AJC not to pressure President Roosevelt on the Jewish issue as he had to deal first with the economic crisis in the United States. Lehman also supported the State Department position that Hitler's persecution of German Jews was an internal German matter (Letter, Judge Irving Lehman to Dr. Cyrus Adler, January 20, 1933 (Adler Papers, AJC Archives, New York City).

6 The quota system limited overall immigration and gave preferences to immigrants from northern and western Europe at the expense of immigrants from southern and eastern Europe.

7 Typical of the mood in the country was the response to the Rogers Wagner bill in 1939 which called for the admission of twenty thousand German children during 1939 and 1940. The bill died in committee. 
reducing the number of refugees from Germany allowed to enter from Germany. ${ }^{8}$ Therefore, they worked to facilitate the issuance of visas within the quota limitation. This proved to be problematic. For example, only thirteen hundred German born persons entered as immigrants in 1933, thirty five hundred in 1934 and three years later in 1937 only eleven thousand. The quota was finally filled in 1938. The actions of American consuls in Germany limited the issuance of visas to German Jews. Many discriminated against Jews, using the Likelihood to Become a Public Charge clause (LPC) of the immigration law. AJC efforts succeeded in allowing for bonds to be posted in the United States to guarantee that the immigrant would not become a public charge. They also managed to have the State Department end the requirement of an immigrant needing a police report from his/her local police department, confirming good behavior. ${ }^{9}$ They also succeeded to exempt German Jewish students on student visas from the requirement that recipients return to Germany after the completion of studies [Lazin 1979].

Clearly, during the 1930s, the AJC (and American Jewry) lacked influence and clout in American politics. They failed to influence their President to criticize Hitler's anti-Jewish policies and actions and they were unable to open the gates of the United States (within the quota allocation) to accept Jewish refugees from Germany. There are many interrelated explanations for their lack of influence and clout.

First, the United States was in the grips of a great economic depression. Tens of millions of Americans were out of work. Unemployment reinforced American isolationism. In Congress a majority favored noninvolvement of the United States in the affairs of Europe and Asia and wanted a minimum or no immigration especially by Jews and other "undesirables." Moreover, anti-Semitism in the United States contributed to the opposition to Jewish immigrants. Different types of antiSemitism thrived in many parts of the United States. The nativist Protestants saw the Jews as foreigners and dangerous; Father Coughlin, a Catholic priest, with the largest radio audience in America, portrayed Jews as the killers of Christ and part of an economic cabal ruling the world; and the German American Bundists, who worshiped Hitler and his ideology, believed Jews to be corrupters of American society and culture.

8 In 1933, the Jewish population of Germany numbered about 520, 000.

9 If a Jewish person fled Germany and applied for a United States visa in Paris, State Department regulations had required his/her going back to Germany to get the document from the local police chief. 
Second, American Jews were insecure in Protestant America. They were seen by others and they saw themselves as outsiders. They were sensitive to anti-Semitism and discrimination in American culture, the media and in the economy. Many leading law firms, banks, major corporations and entire industries did not employ Jews. Higher education institutions limited Jewish enrollments and did not hire Jewish faculty. In many ways they were second class citizens in the United States. Despite the wealth, prominence and success of many in the AJC, they shared this insecurity about their American Jewish identity. Their fear of a potential antiSemitic response, restricted their political activism and advocacy on behalf of their fellow Jews in German. For example, in the late 1930s AJC President, Dr. Cyrus Adler, worried that if the State Department did criticize Hitler's anti-Jewish policies that this might lead many Americans to think that Jews controlled the American government [Lazin 2005: 294].

\section{In the aftermath of World War II (and the Holocaust)}

The events of the Holocaust and the establishment of the State of Israel influenced the post-war standing and status of Jews in the United States. First, the Third Reich's murder of six million Jews made anti-Semitism "socially unacceptable" in the United States. Second, during World War II the tri-faith paradigm of American society [Schultz 2011] triumphed. Catholics and Jews had become "American" in a process of transition begun in the early 1900s. The United States was no longer a Protestant country; it had become a nation of three faiths- Protestant, Catholic and Jewish. Along with these two changes, post war America provided economic and employment opportunities for American Jews. They entered in droves into higher education, law, medicine, business and the media [Silberman 1985]. By the 1960s Jews were overrepresented as students and faculty at many of the better American universities.

The establishment of Israel together with the 1967 War, gave American Jews a new backbone in politics and a great deal of pride in being Jewish. ${ }^{10}$ The Black power movement of the late 1960s, in turn, justified those wanting to view American Jewish interests as a public interest in the United States. ${ }^{11}$ By the 1970s American

10 According to Ralph Goldman [1995: 4,5] “...state of Israel \{psychologically\} changed the Jewish image from that of victim to victor.” Leon Uris's novel Exodus (1958) which retold the story of modern Jewish history culminating in the military prowess of the new Jews of Zion had a similar effect.

11 The Black Power ideology [Carmichael and Hamilton 1967] conceived of their being more than one public interest. 
Jews had become prosperous, suburban and politically influential. In many ways they were mainstream; Goldberg [1996: 4ff] argues that "to some extent American Jews were no longer a minority, but part of a majority in a psychological sense" [Silberman 1985]. For some they had become white. This change in status and influence in American politics is evident in the following case study of the American Jewish advocacy movement for Soviet Jewry.

\section{The American struggle for Soviet Jewry, 1960s to 1989}

Israel became an independent country in May 1948. Following military victory against soldiers from Egypt, Syria, Iraq, Lebanon, Jordan, Saudi Arabia and Yemen, a cease fire and armistice agreements, Israel then confronted a demographic threat of existential proportions. First, its population lacked a critical mass to insure survival (there were too few Israelis) and its relatively large Arab minority with a very high birthrate provided a long-term threat to the Jewish majority in Israel.

To deal with these threats, the government of Israel called on the Jews of the world to immigrate to Israel. Significantly, in the early 1950s, it established a Liaison Bureau (Lishkat Hakesher) to encourage and facilitate the immigration of Jews from the Soviet Union to Israel. ${ }^{12}$ Liaison Bureau emissaries at the Israeli embassy in Moscow worked to preserve Jewish identity and spread knowledge about Israel among Soviet Jews. A second branch worked in Western Europe and the United States to get Western governments to pressure the Soviet Union to grant Jews cultural and religious rights or let them leave for resettlement in Israel. In principle, the Liaison Bureau was not anti-Soviet; it did not call for a regime change. They sought rights for Soviet Jews that were guaranteed in the Soviet constitution. They did, however, accuse the Soviet Union of committing cultural genocide against Soviet Jewry. The Soviets began to let some Jews leave in $1968 .{ }^{13}$

The Liaison Bureau focused its efforts on trying to influence the American government t0 pressure the Soviet Union to allow its Jews to emigrate. It assigned agents to the Israeli Embassy in Washington D.C. and Consulate in New York City. ${ }^{14}$

12 At the time there were two major Jewish communities outside of Israel. One in the United States with almost six million persons and a smaller Soviet Jewish community of between two and three million persons. The Israelis believed that the Soviet Jews were better candidates for immigration; they doubted that many American Jews would want to leave their 'promised land'.

13 The desire to please the United States and its allies often governed Soviet policy toward emigration of Jews. Similar considerations (vis a vis West Germany) also influenced Soviet emigration policy toward their German minority [Lazin 2005].

14 At times its agents also worked at Israeli Consulates in Los Angeles and Chicago. 
The agent in New York recruited American Jewish organizations to the advocacy effort on behalf of Soviet Jewry. In 1971, Liaison Bureau agents helped establish the National Conference on Soviet Jewry (NCSJ) an American umbrella advocacy organization that attracted every major Jewish defense, religious and social organization. The NCSJ led the struggle for Soviet Jewry among mainstream American Jewish organizations. It conducted a public campaign to influence Congress, the State Department and the White House to pressure the Soviet government to act on behalf of Soviet Jewry; let them live as Jews or let them leave for Israel.

At the time President Richard Nixon favored trade with the Soviet Union. He proposed giving Most Favored Nation (MFN) status to the Soviet Union to help it finance trade with the United States. When the Soviet Union initiated an education tax on Soviet Jews leaving for Israel, Senator Jackson (D Washington) proposed an amendment (Jackson Vanik Amendment) denying the Soviets MFN until they allowed free emigration of Jews. ${ }^{15}$

A historic meeting took place on April 30, 1973 between President Nixon and the Conference of Presidents of Major American Jewish Organizations and the NCSJ. In the meeting President Nixon explained that he favored trade with the Soviets and opposed the Jackson Vanik Amendment. He argued that the amendment harmed the interests of the United States. As their President, he asked them to oppose the amendment. Following his presentation, President Nixon left the meeting and those present voted to support the amendment; American Jewish leaders went on record as opposing the President of the United States. Forty years before AJC had refused to publicly criticize the American President. Now, in 1973, the major American Jewish leaders publicly put their concern for Soviet Jews before an interest the President had defined as being 'the national interest.'

In a series of summits between Secretary Mikhail Gorbachev and President Ronald Reagan after 1986 the United States made it clear that détente required granting Soviet Jews the right to leave and religious and cultural freedom for those that remained. In late 1988 the Soviet Union began to open their gates to allow Jews to leave and to grant greater religious and cultural freedom for those that remained. ${ }^{16}$

15 The educational tax required departing Jews to repay the Soviet Union for the higher education and professional training they had received.

16 Following the West's response to the 1979 Soviet invasion of Afghanistan, the Soviet Union, in 1981, closed its gates to Jews wanting to leave the country. 
For many, these decision by the Soviet Union marked the end of the Cold War between the United States and the Soviet Union.

In contrast to the nineteen thirties, American Jewish leaders in the nineteen seventies and eighties had more political success than their predecessors. They succeeded in having their government pressure the Soviet Union to allow free emigration of Jews and cultural and religious rights for those that remained. Moreover, pressure from the American Soviet Jewry advocacy effort helped Soviet Jews to get preferential treatment as persons seeking to enter the United States. From 1968 until late 1989 almost all Soviet Jews wanting to enter the United States did so either as refugees or parolees. ${ }^{17}$

The success of the American Jewish advocacy effort for Soviet Jewry to open the gates of the Soviet Union and to gain preferential treatment for Soviet Jewish refugees in the United States might indicate significant political power and clout for Jews in American politics. However, there is another explanation for the success of advocacy for Soviet Jews. Since the late nineteen-forties, the United States had engaged in a Cold War with the Soviet Union. The Cold War contributed to widespread American political support for advocacy for Soviet Jewry advocacy. The Cold War also gave preference to Soviet Jews wanting to resettle in the United States because they were fleeing the evilest of regimes; and necessarily because of American Jewish pressure to admit them.

Importantly, when the Soviet opened the gates to free Jewish emigration, some sources expected that over a million Jews would leave the Soviet Union. More than ninety percent wanted to come to the United States. In response, with the Cold War ending, the American government imposed a quota in 1989 which limited the entry of Soviet Jewish refugees. ${ }^{18}$

American Jews in the nineteen-seventies and eighties felt more at home and were far less insecure as American Jews than their co-religionists in the nineteenthirties. They were powerful mainstream Americans. When their own government

17 Tens of millions of persons around the world competed for the fewer than one hundred thousand refugee places each year. The Attorney General had the power to parole someone into the United States. The parolee received less financial support than refugees but were also eligible for citizenship.

18 Almost all major American Jewish organizations accepted the quota or limitation on Soviet Jews entering the United States [Lazin 2005]. 
restricted the immigration of Soviet Jews in 1989, they acted with restraint. Most Soviet Jews would go to Israel (many against their wishes); American Jewry did not challenge the government policy to restrict their entry.

\section{The 2016 Elections and Jews in American Politics}

The 2016 presidential election in the United States rattled for many American their sense of security and mainstream status in the American political system. Their concerns focused on the campaigns of Donald Trump for the Republican nomination and as the Republican candidate for President of the United States.

Candidate Trump launched crude attacks on Muslims and immigrants. He portrayed Muslims as being a 'Trojan Horse' and terrorist threat to the well-being of the United States. ${ }^{19} \mathrm{He}$ fabricated tales of Muslim's in New Jersey cheering as the World Trade Center Towers collapsed during the terrorist attacks of September 11, 2001. He described Mexican immigrants as rapists and criminals.

These attacks on Muslim and Mexican immigrants reminded some American Jews of the hostile and threatening atmosphere in the United States of the nineteen-thirties when anti-Jewish views dominated the immigration issue. For example, nativist anti-Semites used the trojan horse metaphor to characterize the threat of admitting German Jewish refugees who might be used by the Nazis to spy on America. Similarly, Trump's negative views of Mexicans and later of African countries recalled the Nazi dehumanization of the German Jews. $^{20}$

Most alarming, however, was the appearance during the campaigns of 2016 of anti-Semitism on social media. When certain Jewish reporters criticized candidate Trump, they were targeted with a barrage of anti-Semitic tweets which sometimes included their photos pasted over drawings of persons being placed in a gas chamber or an oven. Trump's style and campaign normalized anti-Semitic language in public discourse on social media and media in general. For example, a Breitbart article commented on a Jewish correspondent: "Hell hath no fury like a Polish, Jewish American elitist scorned" [Dailkos.com]. Tens of millions of

19 Some of his supporters suggested that adherence to Shariah Law prevented Muslims from becoming real Americans.

20 The reference to Sharia Law recalled the claim by some anti-Semites that adherence to the Talmud and Jewish law prevents Jews from becoming true Americans. 
American heard and or saw a Trump supporter at a rally chant "Jew S A" instead of "USA." 21

In a widely publicized incident candidate Trump retweeted a cartoon from a white supremacist site with a picture of Hillary Clinton surrounded by dollar bills, a six pointed Jewish star, and the caption "most corrupt" [Politifact.com]. While Trump claimed that the cartoon contained a deputy sheriff's star, many Jews saw the ad as an anti-Semitic canard which focused on Jews, money and corruption. And here it is being tweeted by a mainstream American politician, who would soon be President of the United States.

An anti-Semitic message also appeared in Trump's final TV video ad for his presidential campaign [Salon.com]. In the video Trump spoke about how international bankers exploited and drained the wealth from the American economy, hurting middle and working-class Americans. And then three faces of American villains appear in the video-the financier George Soros, the chair of the Federal Reserve Janet Yellen and the CEO of Goldman Sacks Lloyd Blankfein. All three are prominent American Jews who have major roles in the American economy. By implication the ad suggests that they are ripping off the American economy while serving a cabal of international financiers.

The Trump ad reinforced the anti-Semitic claim that Jews control and exploit the American economy. More importantly, Trump refused to condemn or disavow the other more blatant anti-Semitic messages of some of his supporters. Bradley Burston argued that Trump became an "influential public figure who enables, tolerates, excuses and pumps Jew-haters." 22 Some argued that Trump was "dog whistling" the white supremacists. For example, Trump told radio talk show host Alex Jones, who claimed that Jews control the media, "your reputation is amazing" [Vox.com]. When David Duke, former head of the Klu Klux Klan endorsed Trump, Trump refused to disavow him. And after becoming President, when American Nazis marched in Charlottesville, carrying torches and chanting Nazi slogans and "Jews will not replace us" Trump talked about "very fine people' on both sides." ${ }^{33}$

${ }_{21}$ The national news media carried this clip of the event which occurred in Arizona in October 2016.

22 Bradley Burston, "I hadn't been called a kike since fourth grade. Donald Trump changed that." Haaretz October 5, 2016 [Haaretz.com].

23 Https://www.whitehouse.gov/briefings-statements/remarks/ -president- trump-infrastructure/. When Julia Ioffe wrote a critical article about Melanie Trump and received emails urging her to be gassed, Melanie Trump admitted that her fans may have gone too far, but that they were provoked. 


\section{Conclusion}

This article has presented an overview of the status of Jews in American politics from the nineteen thirties to the present. It described a transition of an ethnic and religious minority from being outsiders and peripheral to becoming mainstream and influential actors in American politics. This parallels (or may be the result of) the transformation of the United States, begun in the early twentieth century, from a Protestant country to a tri-faith nation of Protestants, Catholics and Jews. The successful candidacy of Donald Trump for President in 2016 suggests a crisis of identity in the United States. Candidate and President Donald Trump questioned the place of Muslim's and non-white immigrants in American society. Some of his supporters object to the Muslim faith being accepted as a major American faith. They emphasize either the Christian origins and or character of the American way of life and/or America's Judeo Christian heritage. Concurrently, the white supremacist supporters of Trump fear the possibility of whites becoming a minority in a multi-racial United States. The white supremacists consider American Jews to be non-white.

While a minority of American Jews support Trump the overwhelming majority oppose his anti-Muslim and anti-immigration rhetoric and policies. They see his policies and rhetoric as a threat to their own security and well-being as Americans.

The alt right community with its white supremacist contingent may remain small and their political influence may decline. They may return to the fringe and extreme, outside of mainstream American politics. The same fate may await the vocal anti-Semites who surfaced during the 2016 campaign.

Regardless, the events of 2016 have shaken many American Jews who feel more vulnerable than before. The author Nathan Englander writing in the New York Times expressed the change that had occurred. In response to the Nazi march in Charlottesville Virginia with torches, swastikas and the chant "Jews will not replace us" he wrote, "There is the trauma of those assaulted by Nazis on American soil. The pain and violence and the lessons we draw from them. Because the children who witness a day like that, and a president like this, will not forget the fear and disrespect tailored to the black child, the Muslim child, the Jewish child" [NYT.com]. 


\section{Bibliography}

Bauer Y. (1974), My Brother's Keeper: A History of the American Joint Distribution Committee, 1929-1939, Philadelphia: Jewish Publication Society.

Bauer Y. (1981), American Jewry and the Holocaust: The American Joint Distribution Committee, 1941-1945, Detroit: Wayne State University Press.

Carmichael (1967), Stokely and Charles Hamilton. Black Power: The Politics of Liberation, NY: Random House.

Dailkos.com, www.dailkos.com/stories/2016/9/28/1545499/-steve-bannon-website-hellhath-no-fury-like-a-Polish-Jewish-American-elitist.scorned

Goldberg JJ. (1996), Jewish Power: Inside the American Jewish Establishment. Reading, MA: Addison-Wesley.

Goldman R. (1995), The Involvement and Policies of American Jewry in Revitalizing European Jewry, 1945-1995. Unpublished manuscript.

Haaretz.com, www.haaretz.com/misc/article-print-page/i-hadn-t-been-called-a-kike-inyears-trump-changed-that-1.54446 76

Lazin F. (1979), The Response of the American Jewish Committee to the Crisis of German Jewry, 19331939, American Jewish History (formerly AJHQ) LXVIII, No.3 (March, 1979):283304.

Lazin F. (2005), The Struggle for Soviet Jewry in American Politics: Israel versus the American Jewish Establishment, Lexington Books.

NYT.com, www.nyt.com/2017/08/15/opinion/Jewish-charlottesville-anti-Semitism.html

Politifact.com, www.politifact.com/truth-o-meter/article/2016/jul/05/ donald-trumps-star-of-david-tweet-recap/

Salon.com, www.salon.com/2016/11/07/watch-donald-trumps-last-campaign-ad-is-afitting-end-to-an-anti-semitic-campaign/

Schultz K. (2011), Tri-Faith America: How Catholics and Jews Held Postwar America to its Protestant Promise, New York: Oxford University Press.

Silberman C. (1985), A Certain People: American Jews and Their Lives Today, New York: Summit Books.

Ulrich V. (2016), Hitler: Ascent 1989-1939, NY: Alfred A. Knopf.

Uris L. (1958), Exodus, New York: Doubleday and Company.

Vox.com, www.vox.com/policy-and-politics/2016/10/26/13418304/alex-Jones-Jewish-mafia 